\title{
\#USGS
}

science for a changing world

In cooperation with the U.S. Air Force, Aeronautical Systems Center, Environmental Management Directorate, Wright-Patterson Air Force Base, Ohio

\section{Demonstration-Site Development and Phytoremediation Processes Associated With Trichloroethene (TCE) in Ground Water, Naval Air Station-Joint Reserve Base Carswell Field, Fort Worth, Texas}

A field-scale phytoremediation demonstration study was initiated in 1996 by the U.S. Geological Survey (USGS), in cooperation with the U.S. Air Force, at a site on Naval Air StationJoint Reserve Base Carswell Field (NAS-JRB) adjacent to Air Force Plant 4 (AFP4) in Fort Worth, Tex. (fig. 1). Trichloroethene (TCE) has been used at AFP4 in aircraft manufacturing processes for decades; spills and leaks from tanks in the manufacturing building have resulted in shallow ground-water contamination on-site and downgradient from the facility (Eberts and others, 2003). The objective of the study was to determine the effectiveness of eastern cottonwoods (Populus deltoides) in decreasing the mass of dissolved TCE in ground water through phytoremediation. Phytoremediation is a process by which plants decrease the mass of a contaminant through a variety of chemical, physical, and biological means. Before development of the phytoremediation demonstration site, natural attenuation of TCE at the site occurred by sorption, dispersion, dilution, and possibly volatilization (Eberts and others, 2003).

Long-term, field-scale monitoring and evaluation of this site contribute to the understanding of the processes associated with phytoremediation and provide practical information about field-scale applications of the method. This fact sheet briefly

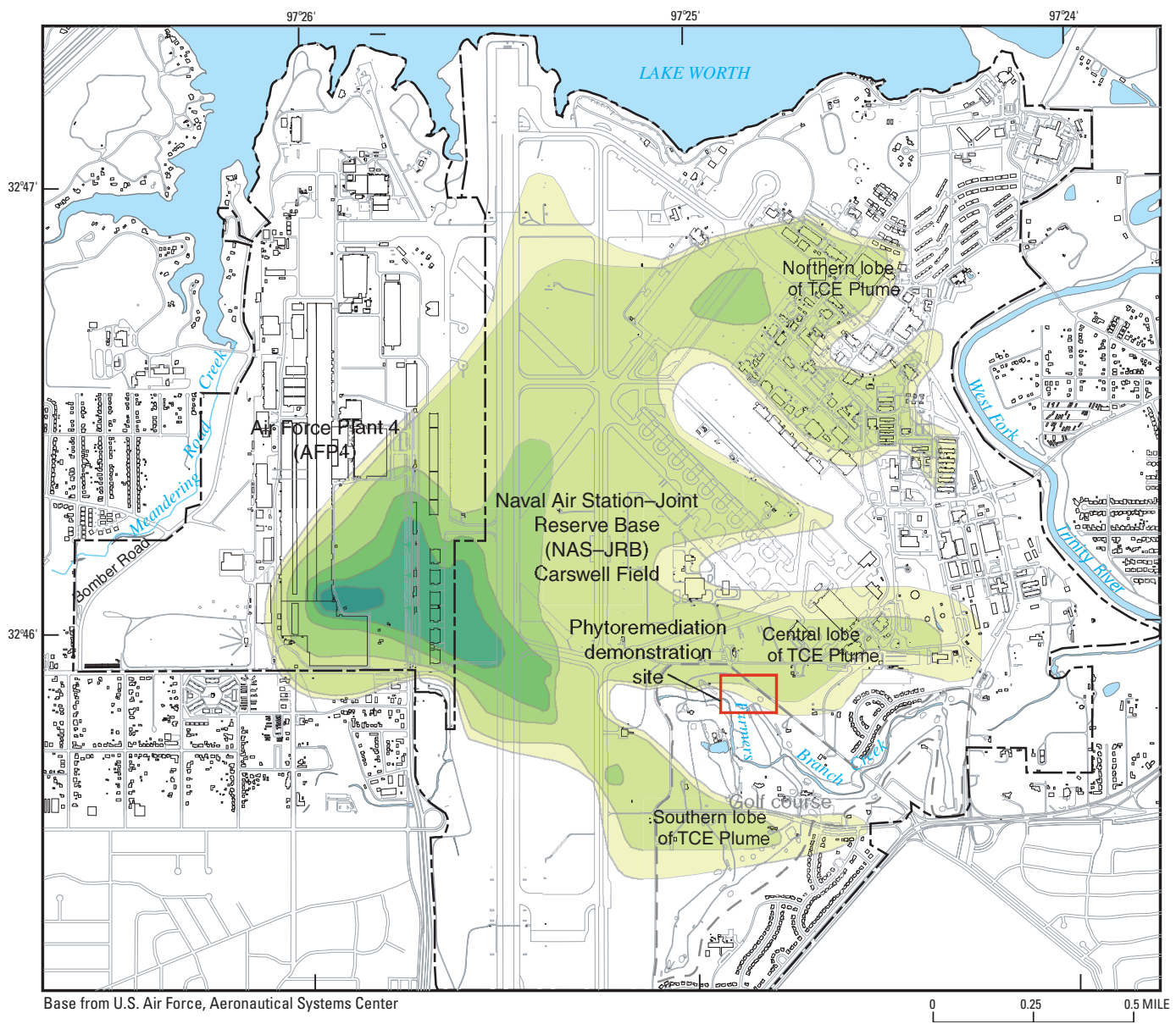

EXPLANATION

Concentration of

TCE, in micrograms per liter

5 to 50

50 to 500

500 to 1,000

1,000 to 5,000

5,000 to 15,000

More than 15,000

AFP4 and NAS-JRB boundary

Study area shown in figure 2

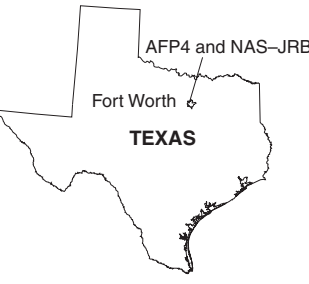

LOCATION MAP

Figure 1. Extent of trichloroethene (TCE) plume in the alluvial aquifer, AFP4 and NAS-JRB, Fort Worth, Texas, fall 2002, and location of phytoremediation demonstration site, NAS-JRB. 


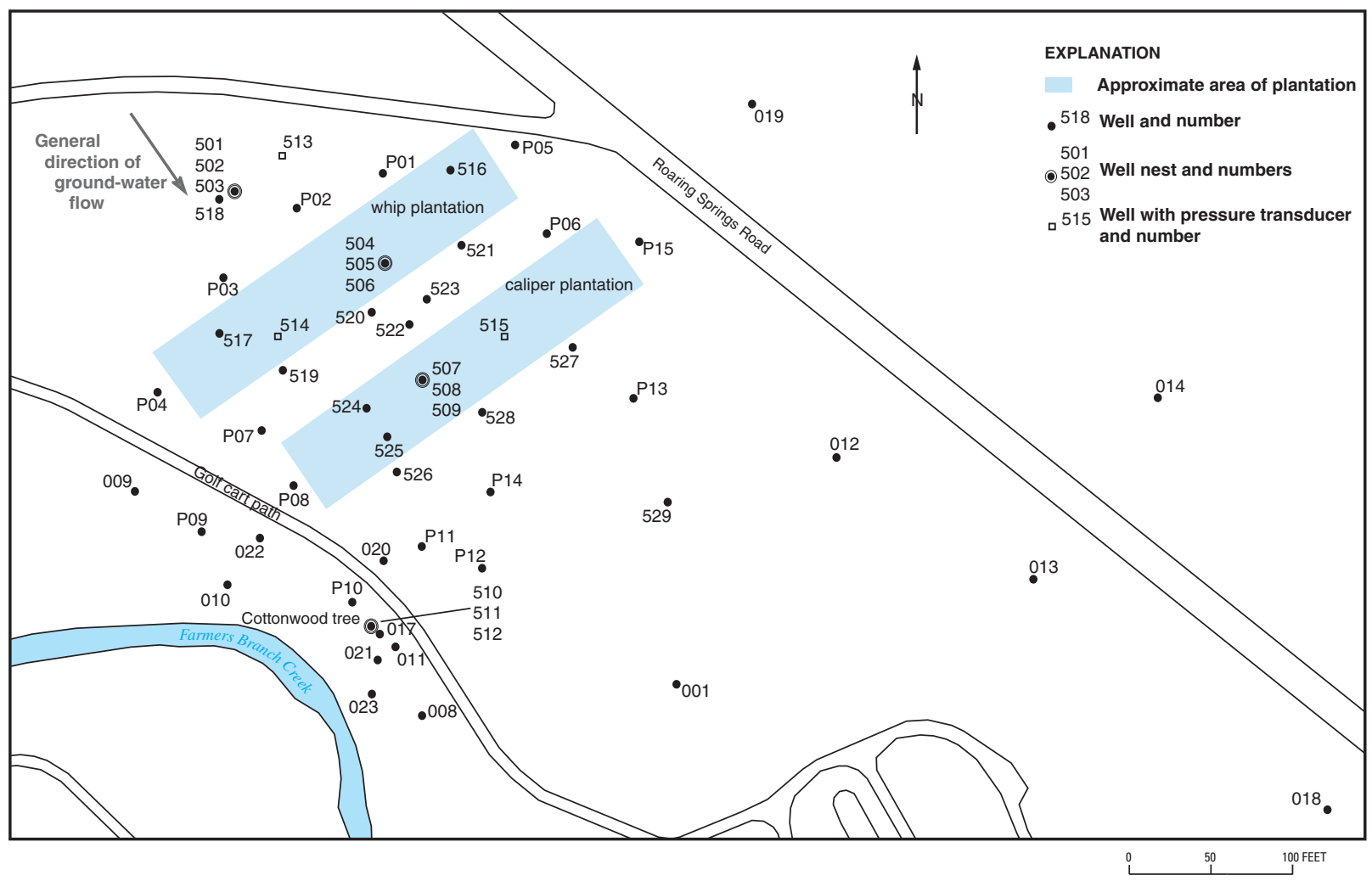

Figure 2. Location of cottonwood plantations and monitor wells at phytoremediation demonstration site, NAS-JRB, Fort Worth, Texas.

summarizes the development of the phytoremediation demonstration site at NAS-JRB and describes some of the physical and chemical processes associated with phytoremediation.

The phytoremediation demonstration site is on the southern edge of the central lobe of a TCE plume in the surficial (alluvial) aquifer. The plume originates at AFP4 about 0.9 mile upgradient from the site (fig. 1). The 9.5 -acre site is in the northwestern corner of the golf course on NAS-JRB. The saturated thickness of the alluvial aquifer, which is composed of clay, silt, sand, and gravel, ranges from about 1.5 to 5 feet at the site. The total thickness of the alluvial aquifer ranges from about 6 to 15 feet. The GoodlandWalnut confining unit, composed of massively bedded shaley limestone, underlies the alluvial aquifer. The general direction of ground-water flow in the study area (fig. 2) is from northwest to southeast, approximately perpendicular to the long sides of the cottonwood plantations. Ground water flows toward Farmers Branch Creek in the area southwest of the golf cart path. At the time of site characterization in August 1996, depth to water ranged from 8 to 13 feet below land surface.

\section{Site Development}

When the study was initiated in 1996, the site was planted with two separate plantations of 1-year-old stems (whips) harvested from branches of eastern cottonwoods during the dormant season and 1-year-old eastern cottonwood seedlings (calipers). Each plantation is about 235 feet long and 50 feet wide and contains seven rows of trees. About 60 trees were planted in each row of the whip plantation, and about 30 trees were planted in each row of the caliper plantation.

Seven rows were trenched in each plantation to a depth of 3 feet with a spacing of 8 feet between rows. The whips, which were about 1.5 feet long, were placed 4 feet apart within the rows, and the calipers, which were more than 6.5 feet tall, were placed 8 feet apart within the rows. Irrigation lines were placed in the trenches along with vegetative material. The trees were watered liberally during the first two growing seasons to encourage deep root development. After the trenches were backfilled, the whips extended about 2 inches above land surface.

The whips were closely spaced to allow for a natural selfdesign of the phytoremediation system. In other words, tree growth and survival were predicted to be dependent upon subsurface heterogeneities. However, closely spaced cottonwoods in other studies have been shown to have smaller diameters and lesser survival rates than widely spaced cottonwoods (Krinard, 1985).

The rate of tree growth above and below land surface at the demonstration site was measured to assess the progression of the phytoremediation system over time. It was important to evaluate the growth rate of the planted trees because differences in cottonwood growth can take time to appear (Cooper and Ferguson, 1979). Such documentation provides insight into the benefits and limitations of the planting strategy used in this demonstration, as well as the ability of the phytoremediation system to influence the ground-water hydrology of the site.

The monitoring system for the site was designed to measure incremental changes in site conditions because phytoremediation processes can require years to develop (Eberts and others, 2003). Ground-water levels were measured in 59 wells, surface-water stage (water level) was measured in Farmers Branch Creek, and rainfall was measured at NAS-JRB. The wells were installed upgradient and downgradient from, within, and surrounding the plantations. Several of the wells were installed adjacent to mature 


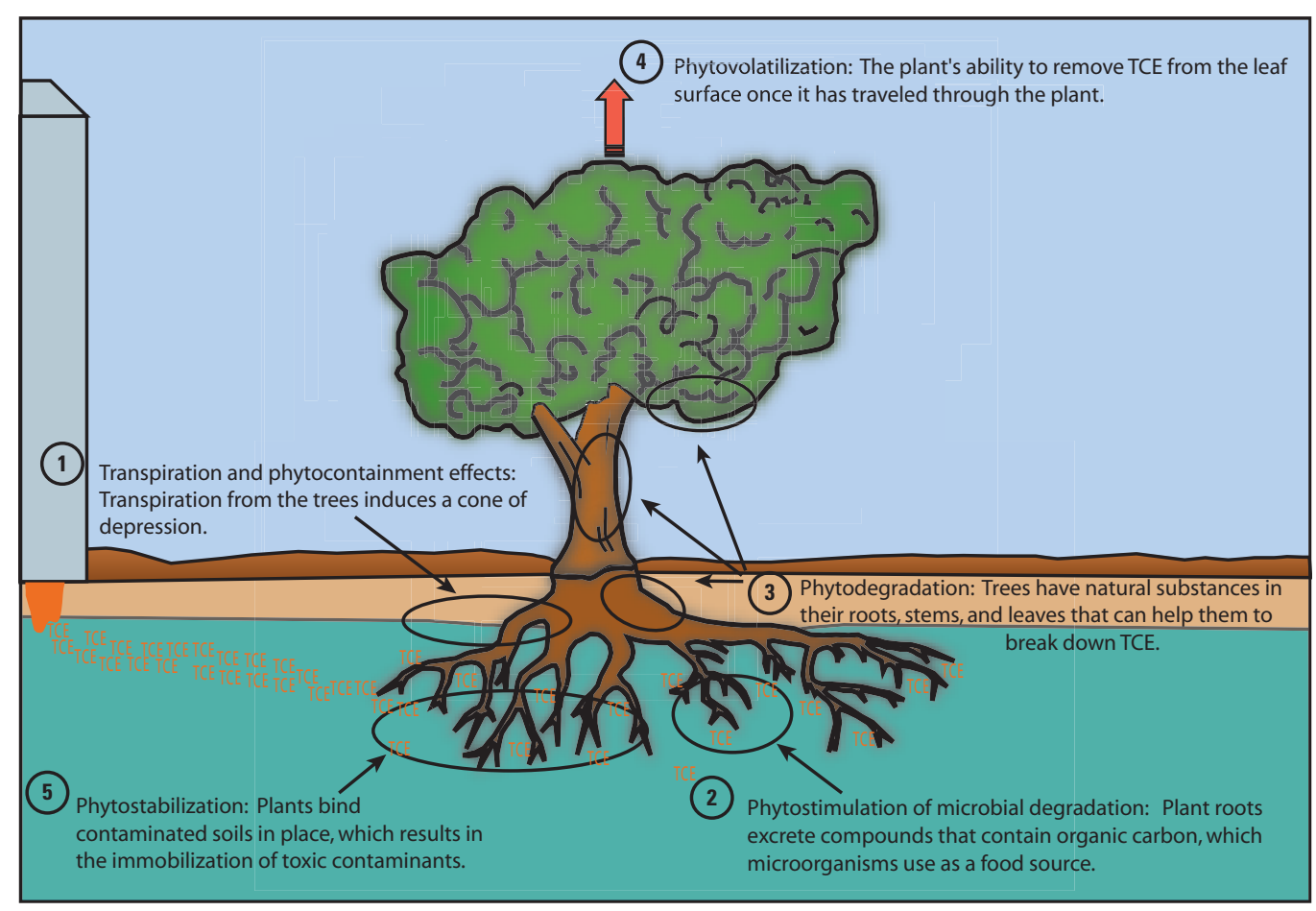

Figure 3. Processes associated with phytoremediation.

trees, including a 19-year-old (in 1996) mature cottonwood tree (fig. 2). Many of the 59 wells were used primarily for measuring water levels. Pressure transducers were placed in three of the wells to measure and record water levels on an hourly basis, including one upgradient from the tree plantations, one in the whip plantation, and one in the caliper plantation.

\section{Processes Associated With Phytoremediation and the Methods Used to Quantify Their Contributions}

The primary objective of the demonstration study was to determine how effectively eastern cottonwood trees decrease the mass of dissolved TCE that is transported within an aquifer across the downgradient end of a planted area. It was hypothesized that tree physiological processes would decrease the mass of TCE in the alluvial aquifer by a combination of hydraulic control of the contaminant plume and in-place biodegradation of the contaminant mass (natural pump and treat). Trees were predicted to remove contaminated water from the aquifer by means of their root systems, followed by the biological alteration of TCE within the trees or the transpiration and volatilization of TCE into the atmosphere. The trees also would promote microbial reductive dechlorination of dissolved TCE within the originally aerobic aquifer (Eberts and others, 2003). Five specific processes (summarized in fig. 3) and methods used to quantify their contributions are described below.

\section{Transpiration and Phytocontainment (Hydraulic Control)}

Transpiration from trees changes horizontal aquifer gradients or vertical soil-moisture pressure gradients, which alters the direction of ground-water flow and might help to contain shallow contaminant plumes or contaminated soil leaching (McCutcheon and Schnoor, 2003); this process is called phytocontainment. The amount of water the planted trees can transpire throughout their life cycle can help to determine, in part, the effectiveness of a phytoremediation system (Eberts and others, 2003). Transpired water can be derived from the nearsurface soils and the saturated zone. The amount of water transpired directly from the aquifer is of interest in this study because TCE and its breakdown products at the site are dissolved in the ground water.

Sapflow was measured in a statistical sampling of trees; from these results an estimate of transpiration for each of the plantations was extrapolated (Vose and others, 2000). Long-term ground-waterlevel hydrographs also were used to estimate transpiration directly from the aquifer (Eberts and others, 2003) using a method developed by White (1932).

\section{Phytostimulation of Microbial Degradation}

A symbiotic relation occurs between plant root systems and microorganisms in the root zone (Motoyama and others, 2001). Plant roots excrete sugars, alcohols, and acids that contain organic carbon, which microorganisms use as a food source. This leads to enhanced microbial activity in the root zone (phytostimulation), which results in an increase in microbial degradation of soil contaminants.

Ground-water samples have been collected about twice each year since 1996 upgradient, downgradient, and within the plantations, as well as beneath the mature cottonwood tree. These samples were analyzed for breakdown products of TCE to assess microbial degradation mechanisms and rates (Eberts and others, 2003).

The spatial distribution of the various microbial populations in the pore water and on the sediment of an aquifer also can be used to assess the mechanisms and rates of microbial degradation in that aquifer. A reconnaissance study of microbial activity in soil and ground water at the site was done in February and June 1998; the results of this study are discussed in Eberts and others (2003).

\section{Phytodegradation}

The uptake of contaminated ground water by the planted trees results in the translocation of contaminants into plant organs (roots, stems, and leaves). TCE might be metabolized within the plant organs; this process is called phytodegradation.

To assess the presence and magnitude of contaminant uptake and translocation of TCE at the phytoremediation demonstration site, samples of roots, stems, and leaves were collected and analyzed for TCE and its breakdown products (Eberts and others, 2003).

\section{Phytovolatilization}

Phytovolatilization is a multimedia transfer of contaminants from water or soil to the atmosphere. Volatile organic compounds are taken up and transpired with water vapor or diffused out of leaves, stems, and roots (McCutcheon and Schnoor, 2003). 
Transpired vapors were not sampled and analyzed from the trees at the demonstration site, but data from a previous study (Newman and others, 1997) indicate that phytovolatilization likely is not a major process associated with phytoremediation of TCEcontaminated ground water.

\section{Phytostabilization}

Phytostabilization refers to the binding of contaminated soils in place by vegetation and the subsequent immobilization of toxic contaminants in soil (McCutcheon and Schnoor, 2003). The establishment of rooted vegetation in the shallow subsurface helps to prevent contaminant migration that occurs as a result of wind and water erosion, soil dispersion, and leaching (U.S. Environmental Protection Agency, 2000). Phytostabilization of organic pollutants that are foreign to living organisms is based on sequestration processes, such as humification (McCutcheon and Schnoor, 2003). Humification refers to the incorporation of organic contaminants into soil organic matter; this reduces bioavailability.

Rising-head slug tests (Bouwer and Rice, 1976) were done at 10 of the wells in 1996 soon after the trees were planted. The tests were repeated in 2003 at most of the 10 wells to help quantify any effects of biological clogging on the aquifer (N.A. Houston, U.S. Geological Survey, written commun., 2004). Phytostabilization effects are difficult to quantify, and sequential slug testing is the only method that has been used to assess these effects at the site.

\section{Interim Findings}

The findings from the 7-year demonstration project support the initial hypothesis that planted eastern cottonwood trees can decrease the mass of TCE in ground water by means of their root systems, followed by the biological alteration of TCE within the trees (Eberts and others, 2003). In addition, the trees can promote in-place microbial degradation of dissolved TCE within the aquifer.

Historical water-quality data collected at the site during the first 7 years of the study indicate that microbial degradation of TCE began to occur within the aquifer during this period, but after 7 years, the aquifer was still in a state of geochemical transition. Oxidation-reduction conditions in the aquifer beneath the planted area are expected to continue in the future, but overall the principal process for decreasing the mass of TCE in the aquifer during the early years of the demonstration has been hydraulic control (Eberts and others, 2003). The relative contributions of transpiration and phytocontainment (hydraulic control) and in-place microbial degradation to the attenuation of the contaminant plume will be assessed after the plantations are judged to be operating at peak efficiency.

These interim findings provide insight into the duration of time (years) necessary for a phytoremediation system to become fully effective. They also demonstrate the importance of long-term monitoring for explaining processes related to changes in an aquifer that can be attributed to planted trees.

\section{References}

Bouwer, Herman, and Rice, R.C., 1976, A slug test for determining hydraulic conductivity of unconfined aquifers with completely or partially penetrating wells: Water Resources Research, v. 12, no. 3, p. 423-428.

Cooper, D.T., and Ferguson, B., 1979, Avoid early selection for growth rate in cottonwood, in Southern Forestry Tree Improvement Conference 15, Mississippi State University, Proceedings: Starkville, Miss., p. $52-58$.

Eberts, S.M., Harvey, G.J., Jones, S.A., and Beckman, S.W., 2003, Multiple-process assessment for a chlorinated-solvent plume, in McCutcheon, S.C., and Schnoor, J.L., eds., PhytoremediationTransformation and control of contaminants: Hoboken, N.J., Wiley, p. 589-633.

Krinard, R.M., 1985, Cottonwood development through 19 years in a Nelder's Design: U.S. Department of Agriculture, Forest Service, Southern Forest Experiment Station, Research Note SO-322, 4 p.

McCutcheon, S.C., and Schnoor, J.L., 2003, Overview of phytotransformation and control of wastes, in McCutcheon, S.C., and Schnoor, J.L., eds., Phytoremediation-Transformation and control of contaminants: Hoboken, N.J., Wiley, p. 3-58.
Motoyama, T., Kadokura, K., Tatsusawa, S., Arie, T., and Yamaguchi, I., 2001, Application of plant-microbe systems to bioremediation: RIKEN Review, no. 42, p. 35-38.

Newman, L.A., Strand, S.E., Choe, N., Duffy, J., Ekuan, G., Ruszaj, M., Shurtleff, B.B., Wilmoth, J., Heilman, P., and Gordon, M.P., 1997, Uptake and transformation of trichloroethylene by hybrid poplars: Environmental Science and Technology, v. 31, no. 4, p. 1,062-1,067.

U.S. Environmental Protection Agency, 2000, Introduction to phytoremediation: Cincinnati, Ohio, Office of Research and Development, National Risk Management Research Laboratory, EPA/600/R-99/107 [variously paged].

Vose, J.M., Swank, W.T., Harvey, G.J., Clinton, B.D., and Sobek, C., 2000, Leaf water relations and sapflow in eastern cottonwood (Populus deltoides Bartr.) trees planted for phytoremediation of a groundwater pollutant: International Journal of Phytoremediation, v. 2, no. 1, p. 53-73.

White, W.N., 1932, A method of estimating ground-water supplies based on discharge by plants and evaporation of soils, results of investigation in Escalante Valley, Utah: U.S. Geological Survey WaterSupply Paper 659-A, p. 1-105.

- Sachin D. Shah and Christopher L. Braun

\section{For additional information, please contact}

District Chief

U.S. Geological Survey

8027 Exchange Dr.

Austin, TX 78754-4733

E-mail: dc_tx@usgs.gov or

Gregory Harvey, ASC/ENVR

Bldg. 8, Suite 200

1800 10th St., Area B

Wright Patterson AFB, OH 45433

E-mail: Gregory.Harvey@wpafb.af.mil
Any use of trade, product, or firm names is for descriptive purposes only and does not imply endorsement by the U.S. Government.

This study was supported by the Superfund Innovative Technology Evaluation Program of the U.S. Environmental Protection Agency, the Environmental Security Technology Certification Program of the Department of Defense, and the Environmental Safety and Health Division of the Aeronautical Systems Center, Engineering Directorate. 